\title{
PENGELOLAAN PANGAN UNTUK PENANGGULANGAN BENCANA DI KABUPATEN LAMPUNG BARAT
}

(Food Management, for Disaster Mitigation in West Lampung District)

\author{
Edwin Kastolani Burtha ${ }^{1}$, Hidayat Syarief ${ }^{2}$, dan Euis Sunarti ${ }^{3}$
}

\footnotetext{
${ }^{1}$ Program Studi Manaj emen Ketahahan Pangan (MKP), Sekolah Pascasarjana, IPB.

2 Departemen Gizi Masyarakat, Fakultas Ekologi Manusia (FEMA), IPB

Tel: 0251-8628304/ 8621258; Fax: 0251-8625846/ 8622276

3 Departemen IImu Keluarga dan Konsumen, Fakultas Ekologi Manusia (FEMA), IPB

Tel: 0251-8628303/ 8627432; Fax: 0251-8625846/8622276
}

\begin{abstract}
Food management is important to understand to avoid food insecurity particularly during disaster. The desain of research was desk study and using secondary data which analysed descriptively at West Lampung district. Food requirement for disaster mitigation were consist of milk formula $668 \mathrm{~kg} /$ day, milk mush $721 \mathrm{~kg} /$ day, rice $33436 \mathrm{~kg} /$ day, noodles instant $23812 \mathrm{~kg} /$ day, sardines $12719 \mathrm{~kg} /$ day, corned beef $8919 \mathrm{~kg} /$ day, abon 7 $677 \mathrm{~kg} /$ day and drinking water $358638.500 \mathrm{ml} /$ day. Food stock utililized for 15 days disaster emergency consist of milk formula $10020 \mathrm{~kg}$, milk mush 10815 kg, rice 501540 kg, instant noodles 357180 kg, sardines 189075 kg, corned beef 133785 kg, abon 115115 kg, and drinking water $5378577500 \mathrm{ml}$. Budged required by goverment of West Lampung district for food stock at 15 days disaster emergency is Rp. 12108365000 . Mechanism and mobilization of food distribution for disaster mitigation conduct by organization unit called Satlak PBP and done by operation unit called Satgas PB.
\end{abstract}

Keywords: food management, disaster mitigation.

\section{PENDAHULUAN}

Memperoleh pangan yang cukup merupakan suatu hal yang sangat penting bagi manusia agar berada dalam kondisi sehat, produktif dan sejahtera. Oleh karena itu hak untuk memperoleh pangan merupakan hak azasi setiap manusia. Data tahun 2007 menunjukkan masih terdapat 5.71 juta jiwa atau $2.55 \%$ penduduk Indonesia rawan pangan dan $48 \%$ daerah yang tergolong rawan pangan (Nainggolan, 2008). Pemenuhan kebutuhan pangan bagi individu, keluarga dan masyarakat menjadi lebih penting lagi disaat situasi dan kondisi tidak normal, seperti saat terjadi bencana. Ketahanan pangan penduduk di Indonesia menghadapi tantangan besar mengingat Indonesia merupakan negara yang rawan bencana alam. Salah satu kabupaten yang rawan bencana adalah Kabupaten Lampung Barat.

Penelitian ini secara umum bertujuan untuk melakukan pengelolaan pangan untuk penanggulangan bencana di Kabupaten Lampung Barat, secara khusus, bertujuan: 1) memetakan wilayah rawan bencana, 2) menghitung ketersediaan pangan aktual, 3) menghitung kebutuhan pangan untuk tanggap darurat bencana, 4) menghitung cadangan pangan pemerintah untuk penanggulangan bencana, 5) menghitung anggaran yang dibutuhkan pemerintah untuk pangan guna penanggulangan bencana, dan 6) merumuskan mekanisme distribusi pangan untuk penanggulangan bencana.

\section{METODE PENELITIAN}

\section{Desain, Tempat dan Waktu Penelitian}

Penelitian dilakukan di Kabupaten Lampung Barat dan berlangsung selama 6 bulan. Penelitian ini merupakan penelitian deskriptif.

\section{Jenis dan Cara Pengumpulan Data}

Jenis data yang digunakan adalah data sekunder yaitu: data kependudukan Kabupaten Lampung Barat, data jumlah kecamatan dan desa Kabupaten Lampung Barat, data produksi pangan Kabupaten Lampung Barat, peta daerah rawan bencana kecamatan di Kabupaten Lampung Barat, peta jalur sesar Kabupaten Lampung Barat, peta rawan banjir Kabupaten Lampung Barat, peta administrasi Kabupaten Lampung Barat, peta epicenter gempa merusak di Pulau Sumatera, data kejadian gempa merusak di Pulau Sumatera, data kejadian gempa merusak di Kabupaten Lampung Barat, data survei konsumsi pangan, data frekuensi 
bencana Kabupaten Lampung Barat, data harga rata-rata bahan pangan Kabupaten Lampung Barat.

\section{Pengolahan dan Analisis Data}

Data sekunder diolah dan dianalisis secara deskriptif. Metode penghitungan kebutuhan pangan untuk tanggap darurat bencana berikut anggaran ditentukan oleh: 1) pendududuk di daerah rawan bencana yang dibagi menjadi usia dewasa ( $>3$ tahun) dan anak ( $<3$ tahun); 2) kebutuhan pangan menurut angka kecukupan energi (AKE); 3) jenis pangan adalah: susu formula, bubur susu, beras, mie instant, sardines, corned beef, abon dan air minum; 4) lama tanggap darurat bencana adalah 15 hari; dan 5) proporsi kontribusi anggaran (dana siap pakai) pemerintah daerah terhadap total kebutuhan anggaran tanggap darurat bencana 15 hari adalah sebesar $50 \%$

Pemetaan daerah rawan bencana merupakan hasil analisis secara deskriptif terhadap data-data dan peta daerah rawan bencana yang sudah ada yang merupakan hasil kajian dari Bappeda Kabupaten Lampung Barat. Ketersediaan pangan aktual berupa beras dihitung dari ketersediaan pangan beras dari produksi kemudian dikoreksi dan dikaji dengan software NBM. Kebutuhan pangan untuk tanggap darurat bencana dihitung dengan menggunakan rumus matematis sederhana yaitu total AKE penduduk dibagi dengan energi yang terkandung dalam pangan prioritas berupa susu, bubur susu, beras, mie instant, sardines, corned beef dan abon kemudian dengan menggunakan asumsi-asumsi tertentu ditentukan kebutuhan pangan untuk tanggap darurat bencana, sedangkan kebutuhan air minum adalah perkalian antara jumlah penduduk dan kebutuhan minimal air minum setiap penduduk setiap hari yaitu untuk usia $<3$ tahun 1.1 liter per hari dan usia $>3$ tahun 2.2 liter per hari. Cadangan pangan untuk penanggulangan bencana dihitung dari kebutuhan pangan untuk penanggulangan bencana berupa pangan prioritas dan air minum dikalikan dengan lama tanggap darurat bencana 15. Anggaran pemerintah yang dibutuhkan untuk pangan guna penanggulangan bencana adalah jumlah cadangan pangan dikalikan dengan harga masing-masing pangan. Mekanisme distribusi pangan adalah dengan menentukan organiasi dan kelembagaan penanggulangan bencana di daerah serta bagaimana pelaksanaan mobilitasi pangan untuk penanggulangan bencana.

\section{HASIL DAN PEMBAHASAN}

\section{Kondisi Wilayah}

Kabupaten Lampung Barat memiliki luas wilayah 495040 ha atau 13.99\% dari luas wilayah Propinsi Lampung dengan jumlah penduduk 410732 jiwa. Secara administratif Kabupaten Lampung Barat terdiri dari 17 kecamatan, dengan 195 Pekon/ Desa dan 6 Kelurahan, berada pada koordinat 4 derajat $47^{\prime} 16^{\prime \prime}-5$ derajat 56'42" Lintang Selatan dan 130 derajat 35'08"-104 derajat 33'51" Buj ur Timur. Wilayah Kabupaten Lampung Barat secara geografis meliputi areal seluas kurang lebih 459040 ha, terdiri dari daerah berdataran rendah (0 - 600 mdpl), daerah berbukit (600 - $1000 \mathrm{mdpl})$ dan daerah pegunungan (1000 - $2000 \mathrm{mdpl}$ ). Formasi geologi yang menyusun wilayah Kabupaten Lampung Barat meliputi formasi alluvium, gamping koral, batuan gunung api kuartier, batuan gunung api, bintuhan, ranau, semung, lemau, hulusimpang, bal, batuan terobosan, lakitan, simpang our dan formasi seblat.

Berdasarkan kondisi fisik demikian, dalam konteks kerentanan terhadap bencana alam, wilayah Kabupaten Lampung Barat dapat dibagi menjadi 3 (tiga) zona utama yaitu: 1) zona I, daerah pesisir, dengan ancaman bencana alam gempa bawah laut dan tsunami, 2) zona II, daerah pegunungan, yang relative paling rentan terhadap bencana: tanah longsor, erosi kuat dan gempa bumi yang juga berperan memicu longsor, 3) zona III, daerah bergelombang, relatif paling aman meskipun tingkat erodibilitas tanahnya kurang lebih sama dengan Zona II dan pada beberapa tempat masih dimungkinkan terkena longsor.

\section{Pemetaan Daerah Rawan Bencana}

Berdasarkan hasil penelitian diketahui bahwa dari 201 pekon/kelurahan di Kabupaten Lampung Barat, terdapat 95 pekon rawan terhadap bencana gempa bumi, banjir, tanah longsor dan tsunami dengan intensitas: 8 kecamatan yang rawan terhadap 1 jenis bencana, 7 kecamatan yang rawan terhadap 2 jenis bencana, 2 kecamatan yang rawan terhadap 3 jenis bencana.

\section{Ketersediaan Pangan Aktual}

Setelah dianalisa berdasarkan Neraca Bahan Makanan Kabupaten Lampung Barat Tahun 2007 dan prioritas jenis pangan yang akan disediakan untuk bencana, maka dalam penelitian ini hanya ketersediaan beras yang akan digunanakan untuk pangan guna penanggulangan bencana. Penyediaan (supply) beras di Kabupaten 
Lampung Barat adalah produksi ditambah impor kemudian dikurangi ekspor, berjumlah 89507 ton beras. Setelah dikurangi pemakaian dalam kabupaten (regional utilization) berupa pakan, bibit, kebutuhan industri dan yang tercecer, maka penyediaan beras untuk makanan (food) adalah berjumlah 87117 ton beras.

Berdasarkan basil perhitungan dalam Neraca Bahan Makanan Tahun 2007, diketahui bahwa jumlah ketersediaan beras untuk konsumsi di Kabupaten Lampung Barat adalah $212.11 \mathrm{~kg}$ per kapita per tahun atau setara dengan 581.12 gram per kapita per hari.

Menurut hasil survei konsumsi pangan Propinsi Lampung, kebutuhan beras untuk konsumsi di Kabupaten Lampung Barat adalah 325 gram per kapita per hari. Apabila ketersediaan pangan aktual berupa beras sebesar 581.12 gram per kap per hari diatas dikurangi kebutuhan konsumsi sebesar 325 gram per kapita per hari, maka terdapat kelebihan beras untuk dikonsumsi sebesar 255.12 gram per kapita per hari atau apabila dibulatkan menjadi sebesar 255 gram per kapita per hari, maka kelebihan beras untuk makanan (food) adalah 38331 ton beras. Kelebihan ketersediaan beras ini adalah bahan makanan yang beredar di masyarakat. Oleh karena itu pemerintah dapat melakukan pembelian beras yang beredar di masyarakat untuk digunakan sebagai cadangan pangan beras pemerintah untuk penanggulangan bencana. jika diasumsikan dibutuhkan 1000 ton beras untuk digunakan dalam tanggap darurat

Tabel 1. Daerah Rawan Bencana di Kabupaten Lampung Barat

\begin{tabular}{|c|c|c|c|c|c|c|c|}
\hline \multirow{2}{*}{ No } & \multirow{2}{*}{ Kecamatan } & \multirow{2}{*}{$\begin{array}{c}\text { Jumlah } \\
\text { Pekon }\end{array}$} & \multicolumn{4}{|c|}{ Jenis Bencana } & \multirow{2}{*}{ Intensitas } \\
\hline & & & Gempa Bumi & Banjir & Longsor & Tsunami & \\
\hline 1 & Balik Bukit & 12 & 4 & 0 & 0 & 0 & 1 \\
\hline 2 & Batu Brak & 11 & 3 & 0 & 0 & 0 & 1 \\
\hline 3 & Belalau & 14 & 2 & 0 & 0 & 0 & 1 \\
\hline 4 & Bengkunat & 5 & 0 & 1 & 0 & 4 & 2 \\
\hline 5 & Bengkunat & 10 & 1 & 3 & 0 & 3 & 3 \\
\hline 6 & Belimbing Gedung Surian & 5 & 2 & 0 & 2 & 0 & 2 \\
\hline 7 & Karya Penggawa & 10 & 0 & 0 & 0 & 6 & 1 \\
\hline 8 & Lemong & 13 & 0 & 0 & 0 & 4 & 1 \\
\hline 9 & Ngambur & 8 & 2 & 0 & 0 & 2 & 2 \\
\hline 10 & Pesisir Selatan & 14 & 5 & 0 & 0 & 5 & 2 \\
\hline 11 & Pesisir Tengah & 22 & 3 & 0 & 1 & 12 & 3 \\
\hline 12 & Pesisir Utara & 17 & 0 & 0 & 0 & 13 & 1 \\
\hline 13 & Sekincau & 10 & 2 & 0 & 1 & 0 & 2 \\
\hline 14 & Sukau & 12 & 5 & 0 & 1 & 0 & 2 \\
\hline 15 & Sumber J aya & 11 & 0 & 0 & 1 & 0 & 1 \\
\hline 16 & Suoh & 12 & 3 & 2 & 0 & 0 & 2 \\
\hline \multirow[t]{2}{*}{17} & Way Tenong & 15 & 0 & 3 & 0 & 0 & 1 \\
\hline & Jumlah & 201 & 32 & 9 & 6 & 49 & \\
\hline
\end{tabular}

Tabel 2. Penduduk Daerah Rawan Bencana per Kecamatan berdasarkan Kelompok Usia di Kabupaten Lampung Barat

\begin{tabular}{|c|c|c|c|c|}
\hline \multirow{2}{*}{ No } & \multirow{2}{*}{ Kecamatan } & \multicolumn{3}{|c|}{ Penduduk di daerah rawan bencana } \\
\hline & & $\leq 3$ th & $>3$ th & Jumlah \\
\hline 1 & Batik Bukit & 450 & 6847 & 7297 \\
\hline 2 & Batu Brak & 184 & 3238 & 3422 \\
\hline 3 & Belalau & 312 & 16574 & 16886 \\
\hline 4 & Bengkunat & 429 & 6605 & 7034 \\
\hline 5 & Bengkunat Belimbing & 434 & 7868 & 8302 \\
\hline 6 & Gedung Surian & 381 & 8016 & 8397 \\
\hline 7 & Karya Penggawa & 512 & 6933 & 7445 \\
\hline 8 & Lemong & 193 & 5481 & 5674 \\
\hline 9 & Ngambur & 263 & 5920 & 6183 \\
\hline 10 & Pesisir Selatan & 532 & 11067 & 11599 \\
\hline 11 & Pesisir Tengah & 1290 & 20162 & 21452 \\
\hline 12 & Pesisis Utara & 301 & 6136 & 6437 \\
\hline 13 & Sekincau & 304 & 11428 & 11732 \\
\hline 14 & Sukau & 820 & 16290 & 17110 \\
\hline 15 & Sumber J aya & 198 & 3187 & 3385 \\
\hline 16 & Suoh & 587 & 15857 & 16444 \\
\hline 17 & Way Tenong & 403 & 7612 & 8015 \\
\hline & mlah Total & 7593 & 159221 & 166814 \\
\hline
\end{tabular}



bencana selama 30 hari, ini berarti pemerintah Kabupaten Lampung Barat dapat memenuhi cadangan pangan beras untuk penanggulangan bencana berasal dari produksi dalam daerah.

\section{Kebutuhan Pangan untuk Penanggulangan Bencana}

Penghitungan kebutuhan pangan untuk penanggulanan bencana didasarkan pada jumlah penduduk yang berada di daerah rawan bencana, sebagaimana terlihat pada Tabel 2 .

Pemilihan pangan untuk pemenuhan kebutuhan zat gizi untuk penanggulangan bencana didasari oleh pertimbangan: 1) pangan dimaksud tidak mudah kadaluarsa/ busuk sehingga awet disimpan untuk jangka waktu yang cukup lama, 2) pangan mudah didistribusikan sehingga akan dapat cepat sampai kepada sasaran 3) pangan mudah dan tidak memerlukan waktu yang lama untuk menyajikannya dan mudah dikonsumsi. Berdasarkan pertimbangan tersebut, maka penulis mengasumsikan bahwa kebutuhan jenis bahan makanan/ prioritas jenis pangan untuk penanggulangan bencana terdiri dari: 1) susu formula dan bubur susu untuk penduduk berusia $<3$ tahun, 2) beras, mie instant, sardines, corned beef serta abon untuk penduduk berusia $>3$ tahun, 3) air minum kemasan untuk seluruh golongan usia penduduk.

Menurut Proboprastowo, Murni dan Dwiriani (2004), kebutuhan energi rata-rata untuk dikonsumsi bagi penduduk berusia $<3$ tahun ialah 735 kkal (merupakan angka rata-rata kebutuhan energi anak berusia 0-3 tahun), sedangkan untuk konsumsi penduduk dewasa adalah $2000 \mathrm{kkal}$. Berdasarkan perhitungan Tingkat Konsumsi/Ketersediaan Energi (TKE) dari Departemen Kesehatan Tahun 1996, kondisi konsumsi/ ketersediaan pangan dapat dikategorikan normal apabila memenuhi $90-119 \%$ AKE. Dengan demikian maka penulis menyimpulkan bahwa ketersediaan energi untuk dikonsumsi saat tanggap darurat bencana bagi penduduk yang dianggap dewasa adalah mengambil angka minimal kebutuhan normal yaitu 90\% dari kebutuhan AKE 2000 kkal yaitu menjadi $1800 \mathrm{kkal}$

Dengan jumlah penduduk berusia $<3$ tahun sebanyak 7593 jiwa dan penduduk berusia >3 Tahun sebanyak 159221 jiwa, maka jumlah total kecukupan energi bagi penduduk daerah rawan bencana, yaitu: 1) golongan penduduk berusia $<3$ Tahun sebesar 5580855 kkal per hari, 2) golongan penduduk berusia $>3$ Tahun sebesar 286597800 kkal per hari. Apabila diasumsikan kebutuhan pangan saat tanggap darurat bencana bagi golongan usia $<3$ Tahun akan dipenuhi dari kedua jenis pangan prioritas dari Susu Formula sebanyak 50\% dan Bubur Susu sebanyak 50\% maka kebutuhan pangan untuk penanggulangan bencana bagi golongan usia <3 Tahun adalah: 1) susu Formula sebanyak $668 \mathrm{~kg}$ per hari, dan 2) bubur susu sebanyak $721 \mathrm{~kg}$ per hari.

Apabila diasumsikan kebutuhan pangan saat tanggap darurat bencana untuk golongan usia >3 tahun sebesar 100\% akan disumbang dari pangan sumber karbohidrat berupa Beras dan Mie Instant sebesar $70 \%$ dan pangan sumber protein berupa Sardines, Corneed Beef dan Abon sebesar 30\% Kebutuhan Beras dan Mie Instan tersebut akan disumbang dari Beras sebesar $60 \%$ dan Mie Instant sebesar $40 \%$ sedangkan kebutuhan Sardines, Corneed Beef dan Abon tersebut akan disumbang dari Sardines sebesar 50\% Corneed Beef sebesar 25\% dan Abon sebesar 25\% maka kebutuhan pangan untuk penanggulangan bencana bagi golongan usia >3 Tahun adalah: 1) beras sebanyak $33436 \mathrm{Kg} /$ hari, 2) mie instant sebanyak 23812 kg/ hari, 3) sardines sebanyak $12719 \mathrm{~kg}$ / hari, 4) corned beef sebanyak 8919 kg/ hari, dan 5) abon sebanyak $7677 \mathrm{~kg} /$ hari.

Kebutuhan air minum untuk orang dewasa adalah sebanyak 2200 mililiter per hari. Berdasarkan rekomendasi Widyakarya Nasional Pangan dan Gizi (WNPG) Tahun 2004 diketahui bahwa kebutuhan air untuk manusia berusia 13 tahun adalah 1100 mililiter per hari. Berdasarkan basil penghitungan diketahui jumlah kebutuhan air minum saat tanggap darurat bencana di Kabupaten Lampung Barat yaitu: 1) air minum golongan usia $<3$ tahun sebanyak 8352 $300 \mathrm{ml}$ per hari, dan air minum golongan usia >3 tahun sebanyak 350286200 ml per hari.

\section{Cadangan Pangan Pemerintah untuk Penang-} gulangan Bencana

Didasari oleh konsep National Food and Security Filipina dan pengalaman tanggap darurat bencana gempa bumi di Yogyakarta, maka dalam penelitian ini akan ditetapkan lama pemberian bantuan pangan dalam masa tanggap darurat apabila terjadi bencana di Kabupaten Lampung barat adalah 15 dan 30 hari. Berdasarkan penghitungan diketahui kebutuhan cadangan pangan untuk tanggap darurat bencana di Kabupaten Lampung Barat adalah sebagaimana terlihat pada tabel 3.

\section{Anggaran Pemerintah untuk Penanggulangan Bencana}

Anggaran pemerintah untuk penanggulangan bencana merupakan dana siap pakai 
yang selalu tersedia dan dicadangkan pemerintah daerah yang akan digunakan pada saat tanggap darurat bencana. Anggaran ini merupakan jumlah cadangan pangan pemerintah yang diperlukan untuk penanggulangan bencana yang dikonversi dalam bentuk anggaran berdasarkan data harga kebutuhan pokok Kabupaten Lampung Barat bulan Nopember tahun 2008, yang disurvei dari pasar tradisional dan pusat ritel.

Berdasarkan penghitungan, maka anggaran pemerintah yang dibutuhkan untuk pangan guna penanggulangan bencana di Kabupaten Lampung Barat, adalah sebagaimana terlihat pada tabel 4.

Berdasarkan Pasal 4 ayat (1) dan (2) huruf b Peraturan Pemerintah Republik Indonesia Nomor 22 Tahun 2008 tentang Pendanaan dan Pengelolaan Bantuan Bencana, disebutkan bahwa dana penanggulangan bencana menjadi tanggung jawab bersama antara pemerintah dan pemerintah daerah dan dana pemerintah daerah berasal dari Anggaran Pendapatan dan Belanja Daerah (APBD). Ini berarti, Pemerintah Daerah Kabupaten Lampung Barat dapat mengalokasikan anggaran kebutuhan cadangan pangan berupa dana siap pakai untuk pangan untuk penanggulangan bencana dalam bentuk APBD.

Apabila diasumsikan bila terjadi bencana Pemerintah Kabupaten Lampung Barat dan pemerintah (pusat) yang diharapkan untuk menanggung anggaran pemenuhan kebutuhan tersebut yaitu sebesar 50-50, maka anggaran minimal (50\%) dana siap pakai untuk pemenuhan pangan guna penanggulangan bencana selama masa tanggap darurat 15 hari yang perlu disiapkan oleh Pemerintah Kabupaten Lampung Barat adalah Rp. 24216730 000,- (Dua puluh empat milyar dua ratus enam belas juta tujuh ratus tiga puluh ribu rupiah). Anggaran ini diasumsikan apabila terjadi bencana secara serentak diseluruh wilayah Kabupaten Lampung Barat. Namun karena pertimbangan kemungkinan terjadinya bencana secara serentak sangat kecil dan juga karena terbatasnya Anggaran Pendapatan dan Belanja Daerah Kabupaten Lampung Barat, penulis menyimpulkan bahwa anggaran sebesar 50\% dari anggaran minimal tersebut sudah cukup memadai untuk ditetapkan sebagai dana siap pakai untuk pemenuhan pangan bila terjadi bencana di Kabupaten Lampung Barat yaitu Rp. 12108365000 (Dua belas milyar seratus delapan juta tiga ratus enam puluh lima ribu rupiah). Anggaran yang dibutuhkan untuk penanggulangan bencana per kapita per hari sesuai dengan golongan usia di Kabupaten Lampung Barat yaitu: 1) golongan usia <3 tahun adalah Rp. 12500 (dua belas ribu lima ratus rupiah), dan 2) golongan usia >3 Tahun adalah Rp. 19000 (sembilan belas ribu rupiah).

\section{Mekanisme Distribusi Pangan untuk Penanggu-} langan Bencana

Pemerintah daerah sebagai pihak yang diberi mandat oleh para pemilih di daerah, berkewajiban antara lain untuk menciptakan kesejahteraan dan memastikan perlindungan kepada warganya. Penanggulangan bencana merupakan salah satu perwujudan fungsi pemerintah

Tabel 3. Cadangan Pangan untuk Penanggulangan Bencana di Kabupaten Lampung Barat

\begin{tabular}{|c|c|c|c|c|}
\hline \multirow[t]{2}{*}{ No } & \multirow[t]{2}{*}{ Jenis Pangan Prioritas } & \multirow{2}{*}{$\begin{array}{l}\text { Kebutuhan } \\
\text { (kg/hr) (ml/hari) }\end{array}$} & \multicolumn{2}{|c|}{$\begin{array}{l}\text { Kebutuhan Pangan Selama Masa } \\
\text { Tanggap Darurat Bencana (kg/hr) }\end{array}$} \\
\hline & & & 15 hari & 30 hari \\
\hline 1 & Susu formula & 668 & 10020 & 20040 \\
\hline 2 & PMT (bubur susu) & 721 & 10815 & 21630 \\
\hline 3 & Beras & 33436 & 501540 & 1003080 \\
\hline 4 & Mie Instant & 23812 & 357180 & 714360 \\
\hline 5 & Sardines & 12719 & 190785 & 381570 \\
\hline 6 & Corned Beef & 8919 & 133785 & 267570 \\
\hline 7 & Abon & 7677 & 115155 & 230310 \\
\hline 8 & Air Minum & 358638500 & 5379577500 & 10759155000 \\
\hline
\end{tabular}

Tabel 4. Anggaran untuk pangan untuk penanggulangan bencana di Kabupaten Lampung Barat

\begin{tabular}{llrrr}
\hline No & Jenis Pangan Prioritas & $\begin{array}{c}\text { Harga Pangan Prioritas dan } \\
\text { Air Minum (Rp/kg) } \\
\text { (Rp/ml)* }\end{array}$ & \multicolumn{2}{c}{$\begin{array}{c}\text { Kebutuhan Anggaran Pangan Selama Masa } \\
\text { Tanggap Darurat Bencana (Rp) }\end{array}$} \\
\cline { 4 - 5 } & Susu formula & 60000 & 601200000 & 15 hari \\
2 & Bubur Susu & 61000 & 659715000 & 1202400000 \\
3 & Beras & 5500 & 2758470000 & 1319430000 \\
4 & Mie Instant & 18000 & 6429240000 & 12858480000 \\
5 & Sardines & 53000 & 1011605000 & 20223210000 \\
6 & Corned Beef & 57000 & 7625745000 & 15251490000 \\
\hline
\end{tabular}


dalam memberikan perlindungan terhadap masyarakat. Agar dapat memberikan perlindungan yang optimal, pemerintah daerah perlu memiliki rencana penanggulangan bencana yang terstruktur, sistematis dan dapat dilaksanakan dengan efektif.

Mekanisme distribusi pangan untuk penanggulangan bencana di Kabupaten Lampung Barat secara organisasi dilakukan oleh Satuan Pelaksana Penanggulangan Bencana dan penanganan Pengungsi (Satlak PBP) sebagai koordinator. Mobilisasi pangan saat tanggap darurat bencana dilakukan oleh Satuan Tugas Penanggulangan Bencana (Satgas PB) dengan dibantu unsur Unit Operasi Penanggulangan Bencana dan Penanganan Pengungsi (Unit Ops PBP) kecamatan. Untuk memudahkan pendistribusian bantuan pangan saat tanggap darurat bencana penulis menyampaikan dua alternatif penempatan cadangan pangan yaitu: a) pemerintah daerah membangun gudang stok cadangan pangan di Kecamatan Balik Bukit, Way Tenong dan Pesisir Tengah, dan/atau b) pemerintah daerah membangun jejaring pangan melalui kerjasama dengan pihak swasta/ distributor ritel yang ada di Kabupaten Lampung Barat.

\section{KESIMPULAN}

Dari 201 pekon/kelurahan di Kabupaten Lampung Barat, terdapat 95 pekon rawan terhadap bencana gempa bumi, banjir, tanah longsor dan tsunami dengan intensitas: 8 kecamatan yang rawan terhadap 1 jenis bencana, 7 kecamatan yang rawan terhadap 2 jenis bencana, 2 kecamatan yang rawan terhadap 3 jenis bencana.

Kebutuhan pangan untuk tanggap darurat bencana di Kabupaten Lampung Barat adalah: 1) susu formula sebanyak $668 \mathrm{~kg} /$ hari, 2) bubur Susu sebanyak $721 \mathrm{~kg} /$ hari, 3) beras sebanyak $33436 \mathrm{~kg} /$ hari, 4) mie instant sebanyak $23812 \mathrm{~kg} /$ hari, 5) sardines sebanyak 12719 $\mathrm{kg} /$ hari, 6) corned beef sebanyak $8919 \mathrm{~kg} /$ hari, 7) abon sebanyak $7677 \mathrm{~kg} /$ hari, dan 8) air minum sebanyak 358638500 ml/ hari.

Cadangan pangan untuk penanggulangan bencana di Kabupaten Lampung Barat dengan skema lama tanggap darurat bencana 15 hari adalah: 1) susu formula sebanyak 10020 kg, 2) bubur susu sebanyak 10815 kg, 3) beras sebanyak 501540 kg, 4) mie instant 357180 kg, 5) sardines sebanyak 190785 kg, 6) corned Beef sebanyak 133785 kg, 7) abon 115155 kg, dan 8) air minum sebanyak 5378577500 ml.
Anggaran pemerintah berupa dana siap pakai yang dibutuhkan pemerintah Kabupaten Lampung Barat untuk pemenuhan cadangan pangan untuk penanggulangan bencana selama masa tanggap darurat bencana 15 hari adalah sebesar Rp. 12108365000 (Dua belas milyar seratus delapan juta tiga ratus enam puluh lima ribu rupiah). Dalam rangka bantuan pangan untuk korban bencana dimana jumlah korban yang membutuhkan bantuan pangan dapat dihitung terlebih dahulu, maka anggaran untuk pangan per kapita per hari korban bencana adalah: a) usia < 3 tahun sebesar Rp. 12500 (Dua belas ribu lima ratus rupiah), dan b) usia > 3 tahun sebesar Rp. 19000 (Sembilan belas ribu rupiah).

Ketersediaan pangan aktual berupa beras untuk tingkat konsumsi adalah 581.90 gram per kapita per hari dan diketahui kebutuhan ideal konsumsi beras Kabupaten Lampung Barat adalah 325 gram per kapita per hari, setelah ketersediaan pangan aktual dikurangi kebutuhan konsumsi maka terdapat kelebihan beras untuk dikonsumsi sebesar 255 gram per kapita per hari atau setara dengan 38331 ton beras. Apabila diasumsikan dibutuhkan 1000 ton beras untuk digunakan dalam tanggap darurat bencana 30 hari, berarti pemerintah Kabupaten Lampung Barat dapat memenuhi cadangan pangan beras untuk penanggulangan bencana berasal dari produksi dalam daerah.

Mekanisme distribusi pangan untuk penanggulangan bencana secara organisasi dilakukan oleh Satlak PBP sebagai koordinator. Mobilisasi pangan saat tanggap darurat bencana dilakukan oleh Satgas PB dengan dibantu unsur Unit Operasi Penanggulangan Bencana kecamatan. Untuk memudahkan pendistribusian bantuan pangan saat tanggap darurat bencana penulis menyampaikan dua alternatif penempatan cadangan pangan yaitu: a) pemerintah daerah membangun gudang stok cadangan pangan di Kecamatan Balik Bukit, Way Tenong dan Pesisir Tengah, dan/atau b) pemerintah daerah membangun jejaring pangan melalui kerjasama dengan pihak swasta/ distributor ritel yang ada di Kabupaten Lampung Barat.

\section{DAFTAR PUSTAKA}

Departemen Kesehatan RI. 1996. Laporan Akhir Konsumsi Gizi. Direktorat J enderal Pembinaan Kesehatan, Direktorat Pembinaan Gizi Masyarakat, Depkes, J akarta. 
Nainggolan K. 2008. Kebijakan Ketahanan Pangan. Disampaikan pada Kuliah Umum Magister Manajemen Ketahanan Pangan Institut Pertanian Bogor. 27 J uni 2008. J akarta.

Proboprastowo, Murni S, \& Dwiriani CM. 2004. Angka Kecukupan Air dan Elektrolit.
Dalam: Soekirman, Ananto KS, Ning $P$, Drajat M, Mewa A, Indrus J, Hardinsyah, Dahrulsyah, Carunia MF, (Eds.), Prosiding Widyakarya Nasional Pangan dan Gizi (WKNPG) VIII; Jakarta, 17-19 Mei 2004. Lembaga IImu Pengetahuan Indonesia (LIPI), J akarta. 